\title{
The vibration signal, modulatory communication and the organization of labor in honey bees, Apis mellifera
}

\author{
Stanley S. SCHNEIDER*, Lee A. LEWIS \\ Department of Biology, University of North Carolina, Charlotte, NC 28223, USA
}

(Received 10 July 2003; revised 17 October 2003; accepted 15 December 2003)

\begin{abstract}
Cooperative activities in honey bee colonies involve the coordinated interactions of multiple workers that perform different, but interrelated tasks. A central objective in the study of honey bee sociality therefore is to understand the communication signals used to integrate behavior within and among worker groups. This paper focuses on the role of the "vibration signal" in organizing labor in honey bee colonies. The vibration signal functions as a type of "modulatory communication signal". It is directed toward diverse recipients, causes a non-specific increase in activity that may alter responsiveness to a wide array of stimuli, and thus may influence the performance of many different tasks simultaneously. We review the empirical evidence that the signal is involved in coordinating at least three colony-level activities: food collection and foraging-dependent tasks, queen behavior during swarming and queen replacement, and house hunting by honey bee swarms. Signals that function like the vibration signal may be widespread in highly social insects and social animals in general, and may help to fine-tune the collective decision-making processes that underlie cooperative actions in a wide array of species.
\end{abstract}

vibration signal / modulatory communication / collective decision making / Apis mellifera / multimodal signals

\section{INTRODUCTION}

Cooperative efforts in social insects are often regulated by collective decisions that emerge through decentralized systems of control (Seeley, 1995; Beshers et al., 1999; Camazine et al., 2001). Many colony activities require the interaction of multiple worker groups that perform interrelated tasks, but which respond to different stimuli, attend to different aspects of the colony environment, and may be congregated in different regions of the nest. A central challenge in the study of insect sociality, therefore, is to understand the mechanisms used to organize information flow and integrate labor within and among worker groups, so that a colony functions as a coherent whole.
At the heart of cooperative behavior in many social insects is a complex system of communication signals that influence worker task performance. These signals can be divided into two main categories based on how they influence worker behavior. The first category includes signals, such as the waggle dance, tremble dance and grooming dance of honey bees, which are produced in specific contexts, influence only certain workers and elicit specific responses. These signals help to organize one or a few specific tasks within particular groups of workers, most of which respond to the same stimuli. But, how is activity coordinated among different worker groups, which often attend to different sets of stimuli? Such coordination may be governed in part by a second category of signals,

\footnotetext{
* Corresponding author: sschnedr@email.uncc.edu
} 
referred to as "modulatory signals" (Markl, 1985). These signals are produced in a variety of contexts and elicit nonspecific effects that shift slightly the probability of engaging in other behavioral acts (Hölldobler and Wilson, 1990). Because of their generalized manner of operation, modulatory signals can influence many different workers and alter the performance of many different activities simultaneously. Modulatory signals may therefore be an important component in the organization of labor in honey bees, and social insects in general (Hölldobler and Wilson, 1990; Beshers et al., 1999; Hölldobler, 1999). However, compared to our knowledge of specific-functioning signals, our understanding of modulatory signals is rudimentary.

An example of a modulatory signal is the vibration signal of the honey bee, which consists of a worker rapidly vibrating her body dorso-ventrally for 1-2 s, usually while grasping a recipient with her forelegs. Vibrating bees typically roam over large areas of the nest and produce series of signals (up to 20 or more per min) that last from several minutes to over an hour (Schneider, 1986; Nieh, 1998; Lewis et al., 2002; Schneider and Lewis, 2003). The vibration signal is one of the most commonly occurring communication signals in honey bee colonies and is performed on many different recipients, including workers of all ages, laying queens, virgin queens and developing queen cells (Painter-Kurt and Schneider, 1998 a, b). It causes a general increase in activity that influences a wide array of cooperative interactions, including foraging, brood care, queen rearing, colony reproduction and swarm movements (Schneider and Lewis, 2003). The signal is therefore used in many different contexts and may have a broad utility in colony life.

However, controversy has surrounded the function of the vibration signal and we have only recently begun to understand its role in honey bee social behavior. Indeed, even the name of the signal has been the subject of debate. Over the years, it has been referred to as the "joy dance", "good-time dance" and the "dance of contentment" (Haydak, 1929, 1945), the "spirit-tap dance" and "pep-tap dance" (Milum, 1955), the "dorso-ventral abdominal vibration" or "D-VAV" (Milum, 1955; von Frisch, 1967; Fletcher, 1975), "shaking", the "shaking dance", and the "jerking dance", (Rütteltanz: from the German rütteln, to jiggle, shake or vibrate) (Schick, 1953; Allen, 1958, 1959a, b; Gahl, 1975; von Frisch, 1967), the "trembling movement" or "vibration movement" (Zitterbewegung: from zittern, to shiver, tremble or vibrate) (Hammann, 1957), the "vibratory dance" (von Frisch, 1967; Fletcher, 1978a, b; Bruinsma et al., 1981), the "vibration dance" (Schneider, 1986, 1987, 1989; Schneider et al., 1986a, b); the "shaking signal" (Seeley et al., 1998; Nieh, 1998; Biesmeijer, 2003), and the "vibration signal" (Painter-Kurt and Schneider, 1998a, b; Visscher et al., 1999; Lewis et al., 2002; Lewis and Schneider, 2000; Donahoe et al., 2003; Schneider and Lewis, 2003). Von Frisch (1967) and Fletcher (1978a) cautioned against the use of the "shaking" nomenclature, noting that this created confusion because "shaking" had already been identified as a synonym for the grooming dance. In the earlier literature, the most commonly used name was the D-VAV. However, this is an inaccurate acronym, because it is not only the abdomen that is vibrated (Visscher et al., 1999). In addition, the behavior does not involve the complex motions of honey bee "dances" and is more appropriately referred to as a signal. Therefore, we use the term "vibration signal", because it accurately describes the tightly controlled, up-and-down motions produced and clearly distinguishes the signal from the more "shaking-like" and "trembling-like" signals such as the grooming dance and tremble dance.

The purpose of this review is to summarize the existing information on the vibration signal and examine its role in cooperative activities of honey bees. Our review has three main goals. First, we explore the modulatory nature of the signal by examining: (1) the workers that perform vibration signals and the factors associated with signal production, (2) the recipients of vibration signals and the responses elicited, and (3) the possible message and meaning of the signal. Second, we examine how the signal may help to organize three cooperative interactions: food collection and foraging-dependent tasks, colony reproduction and queen replacement, and house hunting by swarms. Finally, we address the possible role of modulatory communication in 
collective decision making in honey bee societies, and social systems in general.

\section{THE MODULATORY NATURE OF THE VIBRATION SIGNAL}

\subsection{Signalers and the factors associated with vibration signal performance}

Studies that have monitored marked bees have revealed that, on average, only about $13 \%$ of workers ever perform vibration signals during their life times (Painter-Kurt and Schneider, 1998a, b). However, within this subset of workers, signal production is not restricted to particular age groups. The majority of vibration signals are produced by older workers of foraging age (Gahl, 1975; PainterKurt and Schneider, 1998a, b). Nevertheless, workers of all ages greater than two days old have been observed to perform vibration signals on workers, queens and queen cells (Allen, 1959a; Gahl, 1975; Painter-Kurt and Schneider, 1998a, b).

The broad age range of vibrating bees suggests that signaling activity is not associated with any particular aspect of colony labor and, indeed, a wide variety of factors may influence signal production. Many of the vibration signals performed on workers are produced by foragers, and foraging success may be the primarily factor that stimulates signaling behavior by older bees (Schneider, 1986; Painter-Kurt and Schneider, 1998a; Seeley et al., 1998; Nieh, 1998; Biesmeijer, 2003). However, $10-20 \%$ of the total signalers in a colony are young bees that have no observable association with food collection or foragingrelated tasks (Painter-Kurt and Schneider 1998a). About a third of these young vibrators perform signals during periods of orientation flight (Painter-Kurt and Schneider, 1998a; Biesmeijer, 2003), which suggests that signals performed on workers may be triggered by different stimuli in different signaler age groups. Furthermore, vibration signals can also be produced in response to queen behavior. Signals may be triggered by queen activity level, because both laying queens and virgin queens receive more vibration signals when inactive than active (Schneider, 1990; but see Fletcher, 1978a). Signals performed on queens cells may be influenced by queen emergence behavior (Bruinsma et al., 1981; Fletcher, 1978a) and may also be associated with some aspects of queen pupal development (Schneider and DeGrandi-Hoffman, 2002; see Sect. 3.2)

Thus, vibration signals are produced by a small proportion of workers in response to different stimuli, depending upon signaler age and contextual cues. The generalized nature of vibration signal performance may therefore allow this one signal to influence many different cooperative activities in honey bees.

\subsection{Recipients of the signal and the responses elicited}

Vibration signals are focused on certain recipients that are chosen from an array of potential receivers. As a vibrating bee roams throughout the nest, she contacts hundreds of different workers of all ages that are engaged in many different activities (Gahl, 1975; Schneider, 1985, 1986; Nieh, 1998; Lewis et al., 2002). However, less than half of these bees receive vibration signals, while the remainder are "bypassed" (antennated but not vibrated; Lewis et al., 2002). Recipients are not selected based on age or relatedness, nor is signaling activity directed preferentially toward bees associated with certain tasks (Lewis et al., 2002). Rather, the likelihood of a worker receiving vibration signals may be influenced by her activity level. Both active and inactive bees can be vibrated; however, there is a slight, but significant tendency to direct signaling activity toward less active workers of all ages (Lewis et al., 2002).

Workers respond to the vibration signal with increased activity (Schneider and Lewis 2003). This change in behavior is not immediate and often does not become detectable until 15-30 min after the signal has been received (Schneider et al., 1986a; Schneider, 1987; Schneider and McNally, 1991; Nieh, 1998). The effect of the signal is most often expressed as heightened locomotion (Schneider et al., 1986a; Nieh, 1998), but is also manifested as greater task performance (Schneider, 1987; Schneider and McNally, 1991). The specific tasks performed depend in part upon a recipient's age. Foraging-age recipients respond by moving to the "dance area" near the entrance of the nest, where they have an increased 
likelihood of contacting the waggle dances and odor cues that recruit them to food sites (Schneider et al., 1986a; Nieh, 1998). In contrast, younger workers respond with increased time spent in in-hive tasks, such as brood care, food processing, and comb manipulation (Schneider, 1987; Schneider and McNally, 1991).

The vibration signal may influence worker behavior by affecting response thresholds. The heightened locomotion elicited by the signal could increase contact with other signals and cues, so that a recipient more quickly reaches the threshold for triggering a specific response. Additionally, the signal could lower response thresholds so that less stimulation is required to activate the performance of a particular task. The juvenile hormone $(\mathrm{JH})$ titers of workers 15-30 min after receiving vibration signals are slightly, but significantly higher than those of non-vibrated control bees that are matched for age, location in the nest and initial activity levels (Schneider, Huang and Lewis; unpublished data). The function of the increased $\mathrm{JH}$ titers is unknown. However, $\mathrm{JH}$ contributes to the changing response thresholds associated with the age-based division of labor in honey bees, and may also affect behavior on more short-term time scales (Huang and Robinson, 1999; Elekonich et al., 2001). This raises the possibility that the delayed, non-specific influence of the vibration signal may arise from a physiological effect that could potentially alter responsiveness to a wide array of stimuli. This, in turn, could facilitate the integration of multiple stimuli and result in more fine-tuned decisions by individual bees (Nieh, 1998). Thus, in foraging-age recipients the vibration signal may interact with waggle dances, tremble dances and odor cues to help formulate specific decisions about food gathering. In younger workers, the signal may work in conjunction with brood pheromones, cues emanating from food comb, and interactions with other bees to determine responses consistent with an individual's age and physiological state. By being performed on bees of all ages and influencing response thresholds, the vibration signal can affect many different activities simultaneously and may help to organize information flow among worker groups that perform interrelated tasks.

\subsection{The message and meaning of the vibration signal}

Given the variability in the age of vibrators and recipients, the different stimuli associated with signal performance, the wide range of responses elicited, and the many contexts in which the signal is used, it has been unusually difficult to determine the message conveyed by signalers and the meaning of the vibration signal to receivers. Allen (1958) suggested that the message was "prepare for flight", based on her observations that queens receive vibration signals only during the periods that precede swarming or mating flights. In contrast, Fletcher (1975, 1978a, b), who also monitored signals performed on queens, proposed an opposite message for the vibration signal, namely "reduce your activity". However, subsequent work has suggested that vibration signals are associated with increased activity in all recipients, including queens (Schneider, 1991), which led Seeley et al. (1998) to propose the general message "prepare for greater activity". Nieh (1998) suggested that the signal conveys the message "reallocate labor for different activities or activity levels", based on observations that (1) vibrated workers can increase the number of tasks performed (Schneider, 1987; Schneider and McNally, 1991) and (2) vibration activity often increases at the end of the day when foraging is ceasing, but tasks such as food processing and brood rearing must continue (Nieh, 1998). In a similar vein, Biesmeijer (2003) suggested that the message of the signal is, "reassess your current activity", based in part on the variability in recipients' responses. However, the latter two proposed messages may be unnecessarily complicated. While recipients have an increased likelihood of switching tasks, they can respond by increasing the time spent performing one task (Schneider, 1987; Schneider and McNally, 1991). Thus, there is not an inevitable reallocation of effort to different activities. Likewise, the variability in worker responses does not necessarily indicate a broad-based reassessment of activity budgets, but rather may simply reflect the strong role of contextual cues in determining a worker's ultimate reaction.

Therefore, we propose that the message of the vibration signal is, "increase your 
activity", with the specific response of a recipient being idiosyncratic and arising from an interaction of her age, physiological condition, genetically influenced response thresholds, work history and the other stimuli impinging on her at the time the signal is received. Thus, inactive recipients may respond by becoming active, whereas already-active recipients may become more active. Some recipients may respond with only increased locomotion, some may increase their performance of one particular task, others may switch to different tasks, while still others may exhibit no observable change in behavior if contextual cues do not trigger specific acts. In this manner, the same signal with a general message can be directed toward many recipients in a variety of contexts and have different specific meanings that generate an array of particular responses. However, the exact mode of operation of the vibration signal remains unclear and definite conclusions must await a more complete understanding of the physiological effects elicited by the signal. Nevertheless, the available evidence suggests that the modulatory nature of the vibration signal makes it especially well suited to influence multiple tasks simultaneously, and thus to help integrate the actions of individual workers into colonylevel behavior patterns.

\section{ROLE OF THE VIBRATION SIGNAL IN ORGANIZING COLONY ACTIVITIES}

\subsection{Food collection and foraging-dependent tasks}

Much of the vibration signal activity that occurs between workers may help to synchronize foraging and related tasks. Many of the activities performed by individual workers must be adjusted to the availability of food in the nest and in the field. For example, brood rearing, food processing and comb construction are performed by different groups of young and middle-aged workers and are dependent upon the rate at which pollen and nectar are harvested and stored in the hive. These tasks, in turn, influence the foraging activity of older workers and the types of resources they gather. Coordinating food collection and foraging-dependent tasks therefore requires the integration of numerous worker groups, and the degree to which this occurs may need to vary with changes in the foraging environment and colony requirements (Winston, 1987; Seeley, 1995). One of the main functions of the vibration signal may be to facilitate the behavioral integration necessary to balance colony labor with resource abundance.

Many vibrating bees show an immediate association with food collection and, on average, $10-25 \%$ intermix signaling activity with waggle dances and tremble dances, or perform vibration signals while carrying pollen loads (Schneider, 1986, 1989; Schneider and McNally, 1991; Nieh, 1998; Painter-Kurt and Schneider, 1998a; Seeley et al., 1998; Biesmeijer, 2003). Several aspects of foraging have been suggested to contribute to signal performance, including: (1) the resumption of food collection after a period of dearth (Schneider et al., 1986b; Seeley et al., 1998); (2) contacting and following waggle dancers (Biesmeijer, 2003); (3) changing colony nutritional needs (Schneider et al., 1986b); (4) higher quality food sources (Painter-Kurt and Schneider, 1998a); and (5) temporal patterns of forage availability (Schneider et al., 1986a, b).

Daily patterns of colony-level vibration activity often show a distinct rhythm that is associated with changes in foraging success (Fig. 1). Small, "minor peaks" of vibration activity occur throughout the afternoon hours and often coincide with increases in waggle dance behavior. Large, "major peaks" of vibration signaling occur in the early morning and can precede the onset of foraging by several hours (Fig. 1) (Schneider, 1986a, b; Nieh, 1998; Biesmeijer, 2003; Schneider and Lewis, 2003). Schneider et al. (1986b) demonstrated experimentally that major morning vibration peaks are abolished if colonies are prevented from foraging for 2-4 days, but are reinstated following 3-4 consecutive days of high levels of food intake. Many of the signals performed during morning peaks are produced by foragers that were successful on previous days (Schneider et al., 1986b; Biesmeijer, 2003). Furthermore, there is a significant, positive relationship between the amount of vibration signaling in the early morning hours and the level of waggle dance activity occurring later 


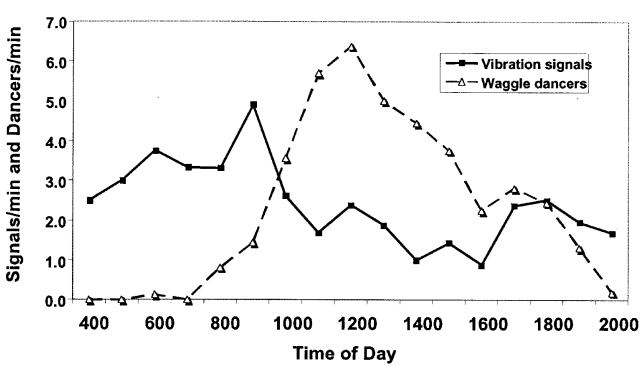

Figure 1. Representative daily patterns of vibration signal and waggle dance activity in a honey bee colony. Signaling activity is typically characterized by small "minor" peaks which occur throughout the afternoon hours and often coincide with increased waggle dance activity. Large "major" vibration peaks occur in the early morning and often precede foraging by several hours. An evening peak of vibration signal activity can also occur at the end of the day when foraging is ceasing.

that same day (Schneider et al., 1986a). Major morning vibration peaks may therefore be based on the foraging success experienced over several preceding days and help to adjust foraging activity for the upcoming day accordingly. Increased vibration activity can also occur in the evening as foraging is ending (Fig. 1) (Schneider et al., 1986a; Nieh, 1998; Biesmeijer, 2003). There is a positive correlation between the height of the major morning vibration peak and the level of evening vibration activity occurring on the same day (Nieh, 1998), which suggests that evening vibration activity may also be associated with the foraging success experienced over an extended period of time.

Thus, daily patterns of vibration signal activity may help to adjust foraging and foraging-dependent tasks on two times scales. Minor vibration peaks may function to adjust food collection and related activities to shortterm changes in foraging success. In contrast, major morning peaks may prime the workforce for the upcoming day's labor relative to long-term trends in food availability. During sustained periods of floral abundance, tasks such as pollen and nectar collection, food processing, comb construction and brood rearing may all need to be increased simultaneously and in a balanced manner. Increased morning vibration activity during these periods could help to achieve this level of behav- ioral integration. Indeed, Nieh (1998) suggested that the daily pattern of vibration activity operates as a "work whistle", with major morning peaks activating foraging and associated tasks at the beginning of the day and evening peaks directing labor more toward in-hive activities at the end of the day. Thus, by responding to foraging success and promoting task performance in different worker groups, the vibration signal may help to adjust numerous aspects of colony labor with both short- and long-term trends in resource abundance.

\subsection{Colony reproduction and queen replacement}

While vibration signals are most commonly directed toward workers, they can also be performed on laying queens (LQs), virgin queens (VQs) and queen cells. However, queens are vibrated only in association with reproductive swarming and queen replacement. During swarming, the LQ must leave the natal nest with about half of the workers and relocate to a new nest cavity. Simultaneously, VQs must be produced in the parental nest to replace the mother queen. Queen replacement also occurs when a failing queen is superceded and in "emergencies" when a laying queen is lost. All instances of queen replacement consist of two distinct phases: (1) 'queen rearing', in which VQs are raised in specially constructed queen cells, and (2) 'queen elimination', in which the number of VQs remaining in the nest is reduced to one (reviewed in Tarpy et al., 2004; Tarpy and Gilley, 2004). Some emerged VQs may depart in secondary swarms, called afterswarms (Winston, 1987). More typically, however, VQs attempt to destroy unemerged "rivals" in queen cells and battle other emerged queens to the death (Gilley, 2001). The end result is a sole surviving VQ that takes mating flights and becomes the new laying queen of the natal nest. Thus, to a large extent, the reproduction and continued survival of honey bee colonies depends upon queen behavior. The vibration signal may be one mechanism used by workers to help to adjust queen activity to the different aspects of the reproductive and queen replacement processes. 


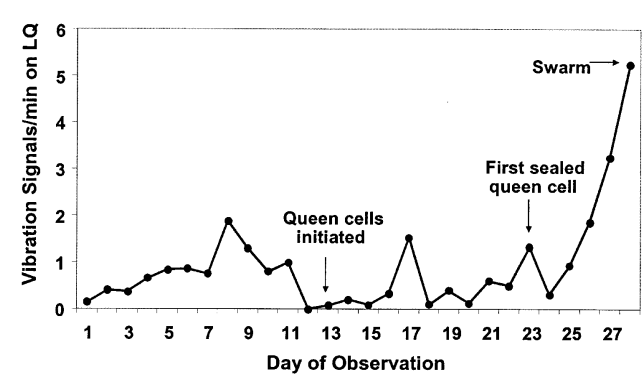

Figure 2. The vibration signal activity performed on a laying queen during the swarm-preparation period.

Laying queens are vibrated only in the 34 week interval when a colony is preparing to swarm. During this period, LQs are vibrated at an increasing rate, and by the final 1-2 days before swarm departure they may receive hundreds of signals each hour (Fig. 2) (Allen, 1958, 1959a; Fletcher, 1975; Schneider, 1991; Painter-Kurt and Schneider, 1998b). Fletcher (1975) suggested that vibration signals inhibit queen activity and are used by workers to prevent LQs from attacking developing queen cells during the swarm-preparation period. However, LQs can be vibrated for several days before queen cells are present (Fig. 2), suggesting that preventing attacks is not the sole function of the signal. Rather, most evidence suggests that a primary role of the vibration signal during swarming preparations is to help gradually prepare laying queens for flight (Allen, 1958, 1959a; Schneider, 1991). LQs receive more vibration signals when inactive than active and respond by walking or running (Schneider, 1991). Also, during swarm-preparation periods, workers decrease the rate at which LQs are fed (Allen, 1960; Schneider, 1990). The combination of increased activity and reduced food intake results in a noticeable weight loss that may be necessary for laying queens to become airborne (Allen, 1958; Schneider, 1991).

In addition to increased locomotion, vibration signals may also influence other aspects of LQ behavior associated with swarming. LQs never leave the nest normally and may pay little or no attention to stimuli associated with the outside world. If vibration signals influence response thresholds, then they may make LQs more likely to react to stimuli that will lead to departure with swarms (Schneider, 1991; Nieh, 1998). The signal may also help to regulate egg laying during the swarming period. Egg production and ovarian development must decline for LQs to achieve flight. However, some oviposition must continue to maintain the worker population in the nest after the queen leaves and allow the rapid resumption of egg laying once the swarm establishes in a new nest. In addition to exhibiting greater locomotion, LQs respond to vibration signals with significant increases in the rates of cell inspection and egg laying (Schneider, 1991). The signal may therefore facilitate laying activity during the period in which ovarian development must decline in preparation for LQ flight.

Vibration signals can be performed on queen cells and virgin queens throughout the rearing and elimination phases of the queen replacement process. Workers often perform the signal on sealed queen cells, sometimes at very high rates. Several authors have reported that queen cells are vibrated repeatedly when VQs are attempting to emerge and that this may delay or prevent emergence (Bruinsma et al., 1981; Fletcher, 1978a). VQs that are allowed to emerge sooner may have a competitive advantage in eliminating rivals (Schneider et al., 2001; Schneider and DeGrandi-Hoffman, 2002). Thus, workers could potentially use the vibration signal to influence the timing of queen emergence and the ultimate outcome of the replacement process. However, Grooters (1987) and Schneider and DeGrandi-Hoffman (2002) found no clear association between the signal and VQ emergence order, while Schneider et al. (2001) found an effect in some colonies but not others. Queen cells can be vibrated for 4-5 days before emergence, suggesting that delaying or preventing emergence is not the sole function of the signal. Schneider and DeGrandiHoffman (2002) found that queen cells vibrated at higher rates were more likely to develop to emergence, whereas those receiving few or no vibration signals had a greater likelihood of being destroyed by workers before development was completed. The signal may therefore help to promote development, although its specific effect on queen cells is unknown. Indeed, the role of the signal during queen rearing remains one of the least 
understood aspects of vibration activity in honey bee colonies.

Vibration signals are also performed on VQs after they emerge. However, there is tremendous variability in the number of signals performed on different queens in the same colony. Some may be vibrated at rates of 200300 signals per hour, while others receive few or no signals (Gilley, 2001; Schneider et al., 2001). VQs that are vibrated at higher rates relative to their sister queens survive longer, eliminate more rivals and are more likely to become the new laying queens of their colonies (Schneider et al., 2001, 2002; Schneider and DeGrandi-Hoffman, 2003). VQs receive more signals when inactive and respond with increased locomotion (Schneider, 1991; but see Fletcher, 1978a). In particular, VQs are often vibrated at high rates when near rivals, which elicits brief bursts of running that may remove them from potential battles and temporarily prevent fighting. VQs can also respond to the vibration signal by producing a pulsed sound called "piping" (Fletcher, 1978a; Schneider, 1991; Gilley, 2001). While the function of piping is not well understood, it may advertise fighting ability and inhibit the emergence of rivals (Visscher, 1993). Queens confined in their cells are often killed by emerged VQs (Gilley, 2001; Schneider et al., 2001; Schneider and DeGrandi-Hoffman, 2003). Thus, the stimulation of piping by the vibration signal could further promote the fighting success of certain VQs and influence the outcome of the queen replacement process (Schneider et al., 2001; Schneider and DeGrandi-Hoffman, 2003). The vibration signal may therefore give workers a degree of control over the behavior of VQs that helps to determine which queen will inherit the natal nest.

However, the cause-and-effect relationship between the vibration signal and VQ success is unclear. The signal might enhance the survival of queens that are vibrated at higher rates, perhaps by delaying their interactions until they have greater maturity and fighting ability. Alternatively, the signal could be used to protect less-vibrated VQs, by temporarily thwarting the attacks of opponents that are vibrated more. The tendency of workers to vibrate some queen more than others could potentially be influenced by paternity (Schneider and
DeGrandi-Hoffman, 2003), relatedness cues (Tarpy and Fletcher, 1998), reproductive capacities (Tarpy et al., 2000), or VQ size and fighting ability (Grooters, 1987; Hatch et al., 1999; Bernasconi et al., 2000). However, we have a limited understanding of the importance of these factors in determining workerqueen interactions (Tarpy and Gilley, 2004). Experimental manipulations of queen characteristics will be necessary to determine the factors that stimulate signal performance and to fully evaluate the relationship between vibration activity and VQ success.

Influencing aggressive interactions is probably not the only function of the signal during queen competition. VQs can be vibrated at high rates more or less continuously for days, and it seems unlikely that such continuous signaling would be necessary to regulate only occasional interactions. Furthermore, VQs continue to receive vibration signals after the rival elimination period is completed. Signaling activity often increases shortly before VQs depart on mating flights (Fletcher, 1978a; Schneider, unpublished data) and continues until egg laying begins. Vibration signals may therefore allow workers to influence not only rival interactions, but also mating flight activity and the onset of oviposition by VQs.

Thus, as has been demonstrated for workers, the vibration signal may act as a nonspecific modulator of queen behavior. By influencing locomotor activity, development, emergence, aggressive interactions, flight behavior and oviposition, the signal may allow workers to coordinate numerous aspects of queen behavior with colony-level reproductive decisions.

\subsection{House hunting by honey bee swarms}

A final cooperative activity that is influenced by the vibration signal is the process of house hunting, in which a swarm of honey bees chooses and moves to a new nest cavity. House hunting consists of two main stages. First, scout bees must locate a variety of potential nest cavities and then winnow the choices down to a single selection. Next, after a cavity has been chosen, the entire swarm must lift off en masse and relocate to the selected site. 
The house-hunting process therefore involves a series of collective decisions and is controlled by at least four different communication signals (see Seeley and Visscher, 2004). Waggle dances are performed by scout bees on the surface of swarm clusters and communicate the location of potential nest cavities. Initially a variety of sites are communicated, but typically all waggle dance activity becomes focused on one location, which represents the new site to which the swarm will relocate (Lindauer, 1955; Seeley and Buhrman, 1999; Camazine et al., 1999; Visscher, 2003). Once large numbers of recruits are visiting one particular nest site, which usually coincides with the onset of consensus among waggle dancers, some scouts begin producing a pulsed sound called "wings-together worker piping" (henceforth referred to as piping) on the swarm cluster (Seeley and Visscher, 2003). Piping is performed at an increasing rate throughout the final hour or so in which the swarm is preparing for departure, and may cause recipients to warm their thoracic muscles to a flight-ready temperature (Seeley and Tautz, 2001). Additionally, shortly before departure some bees begin to perform "buzz running", which consists of a worker running over the swarm in a zigzag pattern while buzzing its wings every second or so (Lindauer, 1955; Esch, 1967). Buzz running may trigger the final break up of the cluster for liftoff (Lindauer, 1955; Martin, 1963), although its role in swarming is unclear (Camazine et al., 1999). A fourth signal involved in house hunting is the vibration signal, which is performed from the time the cluster first forms until the moment of swarm departure (Schneider et al., 1998; Visscher et al., 1999; Lewis and Schneider, 2000). House hunting therefore provides an excellent opportunity to explore how the vibration signal interacts with other communication signals to formulate and adjust collective decisions in honey bees.

Several recent studies suggest that the vibration signal plays a major role in swarm liftoff and movement behavior (Visscher et al., 1999; Lewis and Schneider, 2000). Vibration activity often increases dramatically during the final 30-60 min before departure. During the liftoff-preparation period, numerous workers perform long series of vibration signals while weaving repeatedly into and out of the cluster. Recipients respond with heightened locomotion and an increased tendency to fly, so that as liftoff approaches the entire swarm appears to be in motion and this activity culminates in mass flight (Lewis and Schneider, 2000).

Donahoe et al. (2003) experimentally confirmed the role of the signal in swarm liftoff and movement by removing vibrating bees throughout the house-hunting process. The removal of vibrators increased the duration of the lift-off preparation periods by 4-7 times, caused liftoff attempts to be aborted, and for some swarms may have hindered the ability to move to the chosen nest site once they become airborne. Vibrator removal did not affect the ability of swarms to maintain the high levels of consensus waggle dancing and piping that normally precede departure. The observed changes to liftoff behavior may therefore have resulted directly from diminished vibration signal activity.

Despite the altered liftoff and movement behavior resulting from the removal of vibrators, all experimental swarms ultimately relocated to a new nest site (Donahoe et al., 2003). However, this occurred only after prolonged periods of consensus dancing and piping. These results suggest that the vibration signal may not be essential for the successful completion of house hunting, but it is necessary for the process to happen quickly and efficiently. By generating increased activity in all workers, the signal may enhance responsiveness to waggle dances, piping and buzz running, and may thereby help to integrate the effects of the suite of signals used to formulate decisions for swarm liftoff and movement (Donahoe et al., 2003).

The vibration signal may also influence the nest-site selection stage of house hunting. Most signals produced on swarms are performed by bees of foraging age (Lewis and Schneider, 2000) and this is also the age group that contains the majority of nest-site scouts (Gilley, 1998). About 20\% of vibrating bees perform waggle dances for nest sites, which suggests an immediate association of the signal with scouting and recruitment (Visscher et al., 1999; Lewis and Schneider, 2000). In addition, vibrated recipients have an increased probability of contacting nest-site dancers and flying from the swarm (Lewis and Schneider, 
2000). Thus, during the first phase of house hunting, a portion of vibrators are direct participants in nest-site selection and their signals could work in conjunction with waggle dances to recruit workers to potential nest sites. However, vibration signals are equally likely to be performed by waggle dancers for all sites, suggesting that signaling activity is not used to help focus recruitment on the one site that is ultimately selected for the new nest (Schneider et al., 1998). Similarly, the removal of vibrating bees does not alter the overall level of waggle dance activity observed, the time required to achieve consensus for a nest site, or the rate at which new dancers for the chosen site are recruited (Donahoe et al., 2003). Thus, the role of the vibration signal in nest-site selection is unclear. Future studies should focus on the effect that the vibration signal may have on the number of potential nest sites visited, the area of the environment searched for suitable cavities, and the distribution of recruits among sites.

\section{THE ROLE OF MODULATORY SIGNALS IN COOPERATIVE ACTIVITIES}

While the vibration signal influences food collection, foraging-related tasks, queen replacement, swarming and house hunting, many of these cooperative actions can occur with little or no vibration activity (Schneider et al., 1986a; Gilley, 2001; Schneider et al., $1998,2001)$. Why then is a non-specific signal sometimes used to help orchestrate cooperative activities, when other specific signals and cues exist that alone are sufficient to regulate these behaviors? Perhaps the primary function of the vibration signal is to make fine-tuned adjustments to colony-level decisions. By altering contact with and perhaps responsiveness to other stimuli, the signal could help to adjust the degree of behavioral integration within and among worker groups, and thus to more closely synchronize the interactions necessary for cooperative efforts. Such a function would be consistent with the general effects of the signal, its use in a variety of contexts, its frequent interaction with other specific signals and cues, and its facilitating, but nonessential, role in colony activities.
How might the proposed function of the vibration signal be examined experimentally? If the signal operates to enhance coordination among activities, then vibration activity should increase in situations where greater synchronization is required among different worker groups. There are at least three events that occur naturally in honey bee colonies in which such increased behavioral integration may become necessary. First, when colonies begin to emerge from overwintering, the resumption of brood rearing must be carefully balanced with the energy constraints that arise from dwindling food reserves, diminished worker populations, and limited floral resources during late winter and early spring. Such conditions may require a greater level of coordination among worker groups than typically occurs in colonies that are buffered by large food reserves and worker numbers. Indeed, vibration activity is often greater in colonies in early spring compared to late summer (Schneider, personal observation). Similarly, greater synchronization among tasks may also be required when a swarm founds a new nest. Initially, the energy reserves of the swarm consist almost entirely of the food that workers have stored in their crops, and brood rearing and food processing cannot begin until comb has been constructed. Furthermore, rapid colony establishment and growth are essential to develop the large worker populations and amass the huge food reserves needed for winter survival (Seeley and Visscher, 1985). Thus, during the initial phase of colony founding it may be particularly important that energy budgets remain finely balanced, so that resources devoted to comb building do not compromise brood rearing, or that food collection does not outstrip comb construction and the ability to store and process harvested resources (see Pratt, 2004). Although the vibration signal activity of newly founded nests has never been examined, it would be expected to increase if this facilitates responsiveness to other stimuli and promotes the integration of tasks that must be coordinated with limited energy reserves.

A third situation that could necessitate increased behavioral integration may occur when afterswarms are produced during colony reproduction. In colonies that produce afterswarms, not only must one or more VQs 
depart with portions of the worker population, but VQ aggressive interactions must be controlled to ensure that some queens remain alive for the continuation of the natal nest following swarm departure (Visscher, 1993). The rate at which queens receive vibration signals is typically much greater in colonies that are producing swarms and afterswarms than in those replacing their queens in association with supercedure or queen loss (Schneider et al., 2001). This greater vibration activity may help to synchronize more closely the behavior of different VQs with colony activities associated with the afterswarming process. Thus, overwintering, colony establishment and afterswarming may provide valuable opportunities to assess experimentally the role of modulatory signals in collective decision making and examine how different types of signals interact to organize labor during different phases of the annual cycle of honey bee colonies.

Modulatory communication may be an important factor in the regulation of many social interactions that involve multicomponent systems of communication (Beshers et al., 1999; Hölldobler, 1995, 1999; Partan and Marler, 1999). For example, in numerous species of highly social insects, cooperative activities such as foraging, brood care, nest defense and colony movements are organized by suites of chemical and tactile signals (Hölldobler and Wilson, 1990; Hölldobler et al., 1996; Roces and Hölldobler, 1996; Savoyard et al., 1998). The tactile signals are often "vibration like", in that they involve rapid oscillatory movements of the signaler's body and elicit increased activity in recipients by altering responsiveness to other stimuli (reviewed in Schneider et al., 1986a; Hölldobler, 1995, 1999). These signals frequently function as "catalysts" (sensu Robson and Traniello, 1999), in that their performance is not required for a cooperative activity to occur, but their presence increases the rate at which the group behavior proceeds. Thus, modulatory signals may often help to make fine-tuned adjustments to cooperative activities in social insects that are dependent upon collective responses to sets of communication signals (Hölldobler, 1999). The modulation of responsiveness to other stimuli may also be a feature of many vertebrate species that operate collectively (McGurk and MacDonald, 1976;
Partan and Marler, 1999; Donahoe et al., 2003). Indeed, modulation may be necessary in any system in which individual units that act on only local information must interact within and among subgroups to generate global responses. For example, neuromodulation is a characteristic of all animal nervous systems. Neuromodulators do not generate specific responses, but rather alter the excitability and intrinsic properties of neurons and influence sensitivity to other inputs. These changes, in turn, modify the strength, duration and nature of subsequent activity (Katz, 1995, 1998; Marder and Thirumalai, 2002). Neuromodulation can contribute to the fine-tuning of individual neuronal circuits and to the organization of ensembles of circuits scattered throughout the nervous system, which can ultimately change an animal's behavioral state (Katz, 1999; Marder and Thirumalai, 2002). The responsiveness and flexibility of neural pathways cannot be fully understood without incorporating the effects of neuromodulation (Marder and Thirumalai, 2002). In a similar manner, we may not be able to fully appreciate the subtleties and adaptability of cooperative activities in social animals unless we take into account the role of modulatory communication in group decision making. The vibration signal therefore provides an excellent opportunity for increasing our knowledge, not only of the complexity of honey bee communication, but also of the mechanisms by which modulatory effects are incorporated into the cooperative activities of highly social animals in general.

Résumé - Signal de vibration, communication modulatrice et organisation du travail chez l'Abeille domestique, Apis mellifera. Les activités de coopération chez les abeilles domestiques nécessitent la coordination de nombreux groupes d'ouvrières accomplissant des tâches étroitement liées, mais qui répondent à divers stimuli, contrôlent divers aspects de l'environnement de la colonie et peuvent être répartis dans divers endroits du nid. Un défi central de l'étude de la socialité des abeilles domestiques est de comprendre les signaux de communication utilisés pour intégrer le comportement au sein et entre les groupes d'ouvrières. Les « signaux de communication modulatrice » peuvent être importants pour parvenir à l'intégration comportementale, parce qu'ils influencent de nombreuses ouvrières, suscitent un accroissement général de l'activité et peuvent être utilisés dans une large gamme de contextes. Les signaux modulateurs 
peuvent donc influencer simultanément de nombreuses tâches et aider à coordonner l'activité parmi les ouvrières qui accomplissent des tâches interdépendantes.

Le «signal de vibration » de l'Abeille domestique est un exemple de signal de communication modulatrice. Il est exécuté en réaction à une variété de stimuli, il est dirigé vers les ouvrières de tous âges et suscite une augmentation générale de l'activité qui s'exprime souvent par une locomotion accrue. Le signal provoque également un accroissement des tâches accomplies. Les plus vieilles ouvrières qui reçoivent les signaux de vibration ont une probabilité accrue de s'engager dans la récolte de nourriture et les plus jeunes à passer plus de temps aux travaux d'intérieur tels que les soins au couvain, le traitement du nectar et du pollen et la manipulation des rayons. Le signal peut influencer le comportement de l'ouvrière en modifiant sa sensibilité à d'autres signaux et stimuli, qui en retour déclenchent des actions données. Le message du signal semble être « augmentez votre activité », ce qui, combiné à l'âge, au génotype et à la condition physiologique de la réceptrice, conduit à des réactions spécifiques. Le signal de vibration est donc bien adapté pour influencer simultanément de nombreuses tâches et intégrer le comportement de groupes d'ouvrières qui accomplissent des tâches étroitement liées.

Le signal de vibration peut aider à ajuster au moins trois activités de coopération des colonies d'abeilles. Une grande partie des signaux de vibration est associée au butinage. Les structures journalières d'activité vibratoire peuvent aider à ajuster la récolte de nourriture et les tâches liées au butinage aux variations à court et à long terme de l'abondance florale et des réserves énergétiques de la colonie (Fig. 1). Des signaux de vibration sont également produits pour les reines lors de l'essaimage et de la supersédure. Les signaux peuvent aider à préparer les reines pondeuses à s'envoler (Fig. 2), à influencer le développement et l'émergence de reines vierges et agit sur l'issue de la rivalité entre reines vierges, pouvant ainsi aider à déterminer quelle reine héritera du nid. Enfin des signaux de vibration sont également produits lorsqu'un essaim est à la recherche d'un nouveau nid. Le signal est nécessaire pour qu'il s'envole rapidement et s'installe avec succès dans le nouveau site de nidification.

Le signal de vibration peut donc interagir avec d'autres signaux et stimuli pour aider à accorder avec précision les décisions collectives qui régulent les activités de coopération des abeilles. Les signaux qui fonctionnent comme le signal de vibration sont largement répandus chez les insectes sociaux supérieurs, ce qui laisse penser que la communication modulatrice peut constituer une composante importante dans de nombreuses interactions de coopération qui impliquent des systèmes de communication multicomposants. En fait la modulation peut être nécessaire dans tout système où des unités individuelles doivent interagir à l'intérieur et entre sous-groupes pour produire des réactions importantes. Le signal de vibration fournit donc un excellent système pour étudier non seulement la complexité du système de communication de l'Abeille domestique, mais aussi le rôle de la modulation dans les activités de coopération en général.

\section{Apis mellifera / signal de vibration / communica- tion modulatrice / décision collective / signal multimodal}

Zusammenfassung - Vibrationssignal, modulierende Kommunikation und Organisation der Arbeit bei Honigbienen, Apis mellifera. Die aufeinander abgestimmten Aktivitäten der Honigbienen benötigen eine Koordination von vielen Arbeitsgruppen, die voneinander abhängende Aufgaben durchführen, die aber auf unterschiedliche Reize reagieren, die unterschiedliche Aspekte der Umweltbedingungen des Volks wahrnehmen und die vielleicht unterschiedlich im Nest verteilt sind. Eine zentrale Herausforderung bei der Erforschung des Sozialstaats der Honigbienen ist das Verständnis der Kommunikationssignale für eine Abstimmung des Verhaltens innerhalb und zwischen den Arbeiterinnengruppen. „Signale für eine modulierende Kommunikation" sind wichtig, um diese Integration im Verhalten zu erreichen, weil sie viele verschiedene Arbeiterinnen erreichen, einen generellen Anstieg der Aktivität hervorrufen und in vielen verschiedenen Zusammenhängen benutzt werden können. Modulierende Signale können daher viele Aufgaben gleichzeitig beeinflussen und könnten so helfen, die Aktivitäten von Arbeiterinnen zu koordinieren, die unterschiedliche Aufgaben haben. Ein Beispiel für modulierende Kommunikationssignale ist das „Vibrationssignal“ der Honigbienen. Es tritt als Reaktion auf eine Vielzahl von Reizen auf, betrifft Arbeiterinnen aller Altersstufen, und ruft einen allgemeinen Anstieg der Aktivität hervor, der häufig eine vermehrte Bewegung hervorruft. Das Signal bewirkt auch eine verstärkte Arbeitsleistung. Bei älteren Arbeiterinnen, die das Vibrationssignal wahrnehmen, steigt die Wahrscheinlichkeit zu Sammelflügen. Jüngere verbringen mehr Zeit mit Aktivitäten im Innendienst, wie Brutpflege, Futterverarbeitung und Bearbeitung der Waben. Das Signal kann das Verhalten der Arbeiterinnen durch eine Änderung der Reaktion auf andere Signale und Reize beeinflussen, wodurch wiederum bestimmte Aktionen hervorgerufen werden. Die Botschaft dieses Signals scheint zu sein: ,steigere deine Aktivität", was in Kombination mit dem Alter, dem Genotyp und den physiologischen Bedingungen der Empfänger zu speziellen Reaktionen führt. Deshalb ist das Vibrationssignal gut geeignet gleichzeitig eine Vielzahl von Arbeiten zu beeinflussen und das Verhalten von Gruppen zu integrieren, die voneinander unabhängige Aufgaben durchführen.

Das Vibrationssignal könnte helfen, mindestens drei kooperative Aktivitäten der Bienenvölker 
aufeinander abzustimmen. Ein Großteil der Vibrationssignale beeinflusst das Sammelverhalten. Tägliche Muster von Vibrationsaktivität könnten helfen, Nahrungseintrag und trachtabhängige Aufgaben aufeinander abzustimmen und zwar bei zwei Dingen, kurzzeitige oder andauernde Änderungen im Blütenangebot und in den Energiereserven im Volk (Abb. 1). Vibrationssignale werden auch für Königinnen während des Schwärmens und bei Umweiselung gegeben. Die Signale könnten helfen, legende Königinnen auf den Flug vorzubereiten (Abb. 2), die Entwicklung und den Schlupf von Jungköniginnen zu beeinflussen und Auswirkungen beim Ausgang im Wettkampf der Jungköniginnen zu haben und damit einen Einfluss darauf $\mathrm{zu}$ haben, welche Königin das Nest übernimmt. Schließlich werden Vibrationssignale auch ausgeübt, wenn ein Bienenschwarm eine Nisthöhle sucht. Das Signal ist für einen schnellen und erfolgreichen Start und den Einzug in das neue Nest notwendig. Damit könnte das Vibrationssignal andere Signale und Reize beeinflussen, um eine feine Abstimmung bei kollektiven Entscheidungen bei der Regulation von sozialen Aktivitäten der Honigbienen zu ermöglichen. Signale mit Funktionen wie das Vibrationssignal sind in hoch sozialen Insekten weit verbreitet. Das deutet darauf hin, dass eine modulierende Kommunikation eine wichtige Komponente in vielen kooperativen Interaktionen sein könnte, die beim von vielen Komponenten abhängigen Kommunikationssystem beteiligt sind. In der Tat, eine Notwendigkeit der Modulation scheint in jedem System zu bestehen, in dem einzelne Einheiten innerhalb und zwischen Untergruppen interagieren, um wichtige Reaktionen zu veranlassen. Das Vibrationssignal stellt somit ein ausgezeichnetes System dar, um nicht nur die Komplexität des Kommunikationssystems, sondern auch die Bedeutung der Modulation bei allgemeinen kooperativen Aktivitäten zu untersuchen.

\section{Vibrationssignal / modulierende Kommunika- tion / kollektive Entscheidungen / Apis mellifera / multimodulierende Signale}

\section{REFERENCES}

Allen M.D. (1958) Shaking of honeybee queens prior to flight, Nature 181, 68.

Allen M.D. (1959a) The occurrence and possible significance of the 'shaking' of honeybee queens by workers, Anim. Behav. 7, 66-69.

Allen M.D. (1959b) The 'shaking' of worker honeybees by other workers, Anim. Behav. 7, 233-240.

Allen M. (1960) The honey bee queen and her attendants, Anim. Behav. 8, 201-208.

Bernasconi G., Ratnieks F.L.W., Rand E. (2000) Effect of "spraying" by fighting honey bee queens (Apis mellifera) on the temporal structure of fights, Insectes Soc. 47, 21-26.
Beshers S.N., Robinson G.E., Mittenthal J.E. (1999) Response thresholds and division of labor in insect colonies, in: Detrain C., Deneubourg J.L., Pasteels J.M. (Eds.), Information processing in social insects, Birkhäuser Verlag, Berlin, pp. 115-139.

Biesmeijer J.C. (2003) The occurrence and context of the shaking signal in honey bees (Apis mellifera) exploiting natural food sources, Ethology 109, 1009-1020.

Bruinsma O., Kruijt J.P., van Dusseldorp W. (1981) Delay of emergence of honey bee queens in response to tooting sounds, Proc. Kon. Ned. Akad. Wet. C. 84, 381-387.

Camazine S., Visscher P.K., Finley J., Vetter R.S. (1999) House-hunting by honey bee swarms: collective decisions and individual behaviors, Insectes Soc. 46, 348-360.

Camazine S., Deneubourg J.-L., Franks N.R., Sneyd J., Theraulaz G., Bonabeau E. (Eds.) (2001) Selforganization in biological systems, Princeton Univ. Press, Princeton, NJ.

Donahoe K., Lewis L.A., Schneider S.S. (2003). The role of the vibration signal in the house-hunting process of honey bee (Apis mellifera) swarms, Behav. Ecol. Sociobiol. 54, 593-600.

Elekonich M.M., Schulz D.J., Bloch G., Robinson G.E. (2001) Juvenile hormone levels in honey bee (Apis mellifera L.) foragers: foraging experience and diurnal variation, J. Insect Physiol. 47, 11191125.

Esch H. (1967) The sounds produced by swarming honey bees, Z. Vergl. Physiol. 56, 408-411.

Fletcher D.J.C. (1975) Significance of dorsoventral abdominal vibration among honey-bees (Apis mellifera L), Nature 256, 721-723.

Fletcher D.J.C. (1978a) The influence of vibratory dances by worker honeybees on the activity of virgin queens, J. Apic. Res. 17, 3-13.

Fletcher D.J.C. (1978b) Vibration of queen cells by worker honeybees and its relation to the issue of swarms with virgin queens, J. Apic. Res. 17, 14-26.

Frisch K. von (1967) The dance language and orientation of bees, Harvard Univ. Press, Cambridge, Mass.

Gahl R. (1975) The shaking dance of honeybee workers: evidence for age discrimination, Anim. Behav. 23, 230-232.

Gilley D.C. (1998) The identity of nest-site scouts in honey bee swarms, Apidologie 29, 229-240.

Gilley D.C. (2001) The behavior of honey bees (Apis mellifera ligustica) during queen duels, Ethology 107, 601-622.

Grooters H.J. (1987) Influences of queen piping and worker behaviour on the timing of emergence of honey bee queens, Insectes Soc. 34, 181-193.

Hammann E. (1957) Wer hat die Initiative bei den Ausflügen der Jungkönigin, die Königin oder die Arbeitsbienen? Insectes Soc. 4, 91-106. 
Hatch S., Tarpy D.R., Fletcher D.J.C. (1999) Worker regulation of emergency queen rearing in honey bee colonies and the resultant variation in queen quality, Insectes Soc. 46, 372-377.

Haydak M.H. (1929) Some new observations on the bee life, Ceský Vcel. 63, 133-135.

Haydak M.H. (1945) The language of the honeybees, Am. Bee J. 85, 316-317.

Hölldobler B. (1995) The chemistry of social regulation: Multicomponent signals in ant societies, Proc. Natl. Acad. Sci. USA 92, 19-22.

Hölldobler B. (1999) Multimodal signals in ant communication, J. Comp. Physiol. A 184, 129-141.

Hölldobler B., Wilson E.O. (1990) The ants, Harvard University Press, Cambridge, Mass.

Hölldobler B., Janssen E., Bestmann H.J., Leal I.R., Oliveira P.S., Kern F., König W.A. (1996) Communication in the migratory termite-hunting ant Pachycondyla (= Termitopone) marginata (Formicidae, Ponerinae), J. Comp. Physiol. A 178, 47-53.

Huang Z.-Y., Robinson G.E. (1999) Social control of division of labor in honey bee colonies, in: Detrain C., Deneubourg J.L., Pasteels J.M. (Eds.), Information processing in social Insects, Birkhäuser Verlag, Berlin, pp. 165-186.

Katz P.S. (1995) Neuromodulation and motor pattern generation in the crustacean stomatogastric nervous system, in: Ferrell W.R., Proske U. (Eds.), Neural control of movement, Plenum Press, New York, pp. 277-283.

Katz P.S. (1998) Neuromodulation intrinsic to the central pattern generator for escape swimming in Tritonia, Ann. New York Acad. Sci. 860, 181188.

Katz P.S. (1999) What are we talking about? Modes of neuronal communication, in: Katz P.S. (Ed.), Beyond neurotransmission: neuromodulation and its importance for information processing, Oxford University Press, New York, pp. 1-28.

Lewis L.A., Schneider S.S. (2000) The modulation of worker behavior by the vibration signal during house hunting in swarms of the honeybee, Apis mellifera, Behav. Ecol. Sociobiol. 48, 154-164.

Lewis L.A., Schneider S.S., DeGrandi-Hoffman G. (2002) Factors influencing the selection of recipients by workers performing vibration signals in colonies of the honeybee, Apis mellifera, Anim. Behav. 63, 361-367.

Lindauer M. (1955) Schwarmbienen auf Wohnungssuche, Z. Vergl. Physiol. 37, 263-324.

Marder E., Thirumalai V. (2002) Cellular, synaptic and network effects of neuromodulation, Neural Networks 15, 479-493.

Markl H. (1985) Manipulation, modulation, information, cognition: some of the riddles of communication, in: Hölldobler B., Lindauer M. (Eds.), Experimental behavioral ecology and sociobiology, Fischer, Stuttgart, pp. 163-194.

Martin P. (1963) Die Steuerung der Volksteilung beim Schwärmen der Bienen. Zugleich ein
Beitrag zum Problem der Wanderschwärme, Insectes Soc. 10, 13-42.

McGurk H., MacDonald J. (1976) Hearing lips and seeing voices, Nature 264, 746-748.

Milum V.G. (1955) Honey bee communication, Am. Bee J. 95, 97-104.

Nieh J.C. (1998) The honey bee shaking signal: function and design of a modulatory communication signal, Behav. Ecol. Sociobiol. 42, 23-36.

Painter-Kurt S., Schneider S.S. (1998a) Age and behavior of honey bees, Apis mellifera (Hymenoptera: Apidae), that perform vibration signals on workers, Ethology 104, 457-473.

Painter-Kurt S., Schneider S.S. (1998b) Age and behavior of honey bees, Apis mellifera (Hymenoptera: Apidae), that perform vibration signals on queens and queen cells, Ethology 104, $475-485$.

Partan S., Marler P. (1999) Communication goes multimodal, Science 283, 1272-1273.

Pratt S. (2004) Collective control of the timing and type of comb construction by honey bees (Apis mellifera), Apidologie 35, 193-205.

Robson S.K., Traniello J.F.A. (1999) Key individuals and the organization of labor in ants, in: Detrain C., Deneubourg J.L., Pasteels J.M. (Eds.), Information processing in social insects, Birkhäuser, Berlin, pp. 239-259.

Roces F., Hölldobler B. (1996) Use of stridulation in foraging leaf-cutting ants: mechanical support during cutting or short-range recruitment signal? Behav. Ecol. Sociobiol. 39, 293-299.

Savoyard J.L., Gamboa G.J., Cummings D.L.D., Foster R.L. (1998) The communicative meaning of body oscillations in the social wasp, Polistes fuscatus (Hymenoptera, Vespidae), Insectes Soc. $45,215-230$

Schick W. (1953) Über die Wirkung von Giftstoffen auf die Tänze der Bienen, Z. Vergl. Physiol. 35, $105-128$.

Schneider S.S. (1985) The vibration dance of the honey bee, Apis mellifera: communication associated with the regulation of foraging activity, Ph.D. thesis, University of California, Davis.

Schneider S.S. (1986) The vibration dance activity of successful foragers of the honey bee, Apis mellifera (Hymenoptera: Apidae), J. Kans. Entomol. Soc. 59, 699-705.

Schneider S.S. (1987) The modulation of worker activity by the vibration dance of the honey bee, Apis mellifera, Ethology 74, 211-218.

Schneider S.S. (1989) Dance behaviour of successful foragers of the African honeybee, Apis mellifera scutellata (Hymenoptera: Apidae), J. Apic. Res. $28,150-154$.

Schneider S.S. (1990) Queen behavior and workerqueen interactions in absconding and swarming colonies of the African honey bee, Apis mellifera scutellata (Hymenoptera: Apidae), J. Kans. Entomol. Soc. 63, 179-186. 
Schneider S.S. (1991) Modulation of queen activity by the vibration dance in swarming colonies of the African honey bee, Apis mellifera scutellata (Hymenoptera: Apidae), J. Kans. Entomol. Soc. 64, 269-278.

Schneider S.S., DeGrandi-Hoffman G. (2002) The influence of worker behavior and paternity on the development and emergence of honey bee queens, Insectes Soc. 49, 306-314.

Schneider S.S., DeGrandi-Hoffman G. (2003) The influence of paternity on virgin queen success in hybrid colonies of European and African honeybees, Anim. Behav. 65, 883-892.

Schneider S.S., Lewis L.A. (2003) Honey bee communication: the "tremble dance", the "vibration signal" and the "migration dance", in: Webster T. (Ed.), Monographs in honey bee biology, Northern Bee Books, West Yorks, Great Britain, Vol. 1, pp. 1-26.

Schneider S.S., McNally L.C. (1991) The vibration dance behavior of queenless workers of the honey bee, Apis mellifera (Hymenoptera: Apidae), J. Insect Behav. 4, 319-322.

Schneider S.S., Painter-Kurt S., DeGrandi-Hoffman G. (2001) The role of the vibration signal during queen competition in colonies of the honeybee, Apis mellifera, Anim. Behav. 61, 1173-1180.

Schneider S.S., Painter-Kurt S., DeGrandi-Hoffman G. (2002) Regulation of virgin queen behavior by the vibration signal of the honey bee and its possible role in the Africanization process, in: Erickson E.H. Jr., Page R.E. Jr., Hanna A.A. (Eds.), Proc. 2nd Int. Conf. on Africanized Honey Bees and Bee Mites, A.I. Root, Medina, Ohio, pp. 34-44.

Schneider S.S., Stamps J.A., Gary N.E. (1986a) The vibration dance of the honey bee. I. Communication regulating foraging on two time scales, Anim. Behav. 34, 319-322.

Schneider S.S., Stamps J.A., Gary N.E. (1986b) The vibration dance of the honey bee. II. The effects of foraging success on daily patterns of vibration activity, Anim. Behav. 34, 386-391.

Schneider S.S., Visscher P.K., Camazine S. (1998) Vibration signal behavior of waggle-dancers in swarms of the honey bee, Apis mellifera (Hymenoptera: Apidae), Ethology 104, 963-972.

Seeley T.D. (1995) The wisdom of the hive, Harvard University Press, Cambridge, Mass.
Seeley T.D., Buhrman S.C. (1999) Group decision making in swarms of honey bees, Behav. Ecol. Sociobiol. 45, 19-31.

Seeley T.D., Tautz J. (2001) Worker piping in honey bee swarms and its role in preparing for liftoff, J. Comp. Physiol. A 187, 667-676.

Seeley T.D., Visscher P.K. (1985) Survival of honeybees in cold climates: the critical timing of colony growth and reproduction, Ecol. Entomol. $10,81-88$.

Seeley T.D., Visscher P.K. (2003) Choosing a home: how the scouts in a honey bee swarm perceive the completion of their group decision making, Behav. Ecol. Sociobiol. 54, 511-520.

Seeley T.D., Visscher P.K. (2004) Group decision making in nest-site selection by honey bees, Apidologie 35, 101-116.

Seeley T.D., Weidenmüller A., Kühnholz S. (1998) The shaking signal of the honey bee informs workers to prepare for greater activity, Ethology 104, 10-26.

Tarpy D.R., Fletcher D.J.C. (1998) Effects of relatedness on queen competition within honey bee colonies, Anim. Behav. 55, 537-543.

Tarpy D.R., Gilley D.C. (2004) Group decision making during queen production in colonies of highly eusocial bees, Apidologie 35, 207-216.

Tarpy D.R., Hatch S., Fletcher D.J.C. (2000) The influence of queen age and quality during queen replacement in honeybee colonies, Anim. Behav. 59, 97-101.

Tarpy D.R., Gilley D.C., Seeley T.D. (2004) Levels of selection in a social insect: a review of conflict and cooperation during honey bee (Apis mellifera) queen replacement, Behav. Ecol. Sociobiol., in press, DOI 10.1007/s00265-0030738-5.

Visscher P.K. (1993) A theoretical analysis of individual interests and intracolony conflict during swarming of honey bee colonies, J. Theor. Biol. 165, 191-212.

Visscher P.K. (2003) How self-organization evolves, Nature 421, 799-800.

Visscher P.K., Shepardson J., McCart L., Camazine S. (1999) Vibration signal modulates the behavior of house-hunting honey bees (Apis mellifera), Ethology 105, 759-769.

Winston M.L. (1987) The biology of the honey bee, Harvard University Press, Cambridge, Mass. 